\title{
Morocco's Participative Banking Sector: A Cross-Analysis of Current State, Opportunities and Challenges of Its Five Banks and Three Windows
}

\author{
Oumniya Amrani \\ $\mathrm{PhD}$ Student \\ Interdisciplinary Center for Research in Performance and Competitiveness \\ Faculty of Legal, Economic and Social Sciences \\ Souissi-Mohamed V University, Rabat-Morocco \\ E-mail: oumniya.amrani@gmail.com \\ Amal Najab \\ Professor \\ Interdisciplinary Center for Research in Performance and Competitiveness \\ Faculty of Legal, Economic and Social Sciences \\ Souissi-Mohamed V University, Rabat-Morocco \\ E-mail: a.najab@um5s.net.ma
}

Received: June 06, 2020

Accepted: July 03, 2020

Online Published: July 3I, 2020

doi: I0.4628I/ijibm.v4i2.687

URL: https://doi.org/I0.4628I/ijibm.v4i2.687

\begin{abstract}
Launched two and a half years ago, the model of Islamic banking adopted by Morocco consists of five banks and three windows. This paper aims to present an exploratory case study of the performance of the eight actors of Morocco participative banking. The study reveals an increase of Murabaha funding and deposits while the total net profit remains negative (MAD -420 million) mainly due to the start-up costs absorbing an enormous amount of resources. Presented in a SWOT Analysis, the study's results confirm that the sector is facing many difficulties and gaps that negatively affect the business especially the incomplete participative financial ecosystem. Then, the paper presents a benchmark study of Turkey's participation in banking. Findings show that the financial ecosystem in Turkey is much more developed compared to Morocco. Consequently, this situation favored the rise of the five operational participation banks whose asset growth rate reached 99\%, between 20I4 and 20I8, and recorded positive net profits which exceeded TL 2 billion. Nevertheless, both Morocco and Turkey participation banks are still too young and can make headway only if the regulators and the operators properly address the challenges which hamper their development.
\end{abstract}

Keywords: Morocco Participative Banking, Exploratory Study, SWOT Analysis, Benchmark Study, Turkey's Participation Banking.

JEL Classification: G2I, 057.

\section{Introduction}

Unlike traditional banking, where interest processing is a key product and money is exchanged as a commodity, Islamic banking relies on an interest-free banking system and its financial transactions are necessarily backed by real assets. The risks in this system are shared between the bank and the customer under the principle of sharing losses and profits.

In Morocco, although the central bank approved the launch of Islamic banking institutions in January 2017, officially known as "participative" banking institutions, the effective start of their activities could only take place during the second half of the year. Currently, the banking landscape in Morocco has eight participative banking institutions, including five banks and three participative windows. So, two and a half years of practice, how is the balance sheet of the operators of this new industry? And do these results reflect the existence of a normal size that can be developed, or are they related to a specific financial ecosystem? 
This article aims to present an exploratory study of the five banks and three participative windows operating in the Moroccan banking sector. For this, we will present, analyze, and compare the commercial and financial performance of the eight players of this industry. Financial data is collected from Bank Al Maghrib's annual report on banking activity as well as the annual financial statements of the participative institutions. Then, we will analyze the ecosystem in which these institutions operate to deduce a SWOT Analysis identifying the strengths, weaknesses, opportunities, and threats of the development of participative banking activity in Morocco. Moreover, in the form of a benchmark study, the document sheds light on the participation banks in Turkey and sets out a SWOT Analysis of the Turkish participation banking sector. The aim is to highlight the main divergence and convergence points between the two participative banking systems.

\section{Overview of the Evolution of Islamic Banking Activity in the World}

After the experience of rural savings banks in Egypt between 1963 and 1967, the first private Islamic bank was established in 1975. It is the Dubai Islamic Bank which was launched following the creation of the Islamic Development Bank in Jeddah (IDB) in 1974 (Bari \& Radi, 20II). Since, Sharia-compliant banking has grown and spread around the world, both in countries with a predominantly Muslim population and in Muslim-minority countries (Amrani \& Najab, 2020).

Over the past two decades, Islamic banking has grown and expanded significantly. The liberalization of financial regulations, financial globalization, technological change, and product innovation, are the main factors driving the spread of this industry around the world (Rashwan \& Ehab, 2016). Similarly, the financial crisis that shook the world in 2007 highlighted the resilience of Islamic banks to crises. According to (Hasan \& Dridi, 2012), Islamic banks performed better than conventional banks during this crisis. The profitability of Islamic banks is less volatile and higher than that of conventional banks (Hassoune, 2003).

Moreover, according to the latest statistics presented in the report on the development of Islamic finance (IFDI, 2019), the number of Islamic financial institutions reached I,447 institutions in 20I8, including 520 Islamic banks located in 72 countries around the world. Similarly, Islamic banking assets have totalized I.76 trillion USD, with a growth rate of 35\% compared to 2012. According to the projection for 2024, the total value of the global Islamic banking assets will amount to 2.175 trillion U.S. dollars

As a result, Islamic banking is the largest player in the whole Islamic finance industry, contributing 7I\% (USD I.72 trillion) of the industry's assets. This double-digit growth reflects the big interest in Islamic banking activity among both investors and consumers.

\section{Cross Analysis of Morocco Participative Banking Sector}

The Kingdom of Morocco is the last Muslim country to introduce Islamic banks, officially known as "participative banking institutions", into the national banking sphere. Morocco first introduced Islamic financial products and services, or alternative financial solutions, through conventional financial institutions at the national level in 2007. Therefore, the official presence of "participative banking institutions", as they are called by the regulator, within the Moroccan banking landscape dates to the second half of 2017. Now, the participative banking sphere in Morocco has eight banking institutions, including five banks and three participative windows.

\section{I Design and Methodology}

According to a study conducted by the Islamic Finance Advisory and Assurance Services (IFAAS), the arrival of participative banks was highly anticipated by the majority of the Moroccan population, with about $79 \%$ of respondents said they would be "very interested" in participative banking services once available (IFAAS, 20I4).

The purpose of this paper is to shed light on the current state of Moroccan participative banking institutions to find out how well the forecasts for their success have been achieved. For this, we will proceed by an exploratory case study of each one of the participative banking institutions, starting by the five banks (case study I) and then the three windows (case study 2). To analyze their commercial and financial performances, the data is collected from the Central Bank reports, the annual financial statements, and the websites of the eight players of the participative banking industry. The paper will present later the ecosystem in which those institutions operate to deduce a SWOT Analysis identifying the strengths, weaknesses, opportunities, and threats of the development of participative banking activity in Morocco.

On the other hand, the paper will present a benchmark study of the participation banks in Turkey in general mainly through the statistics and information published by the Participation Banks Association of Turkey (2018). Main findings of the benchmark will be presented ina general SWOT Analysis of the whole Turkish participation banking sector. And the conclusion will present the main similarities and differences between the participative banking sectors of the two countries, according to the results of this study. 


\subsection{Case Study I: The Five Moroccan Participative Banks}

Bank Assafa (BA), Umnia Bank (UB), Al Akhdar Bank (AAB), Bank Al Yousr (BAY), and Bank al Tamwilwa al Inmaa (BTI) are the five Moroccan participative banks.

Table I. Presentation of the five Moroccan participative banks

\begin{tabular}{|c|c|c|c|c|}
\hline Participative banks & $\begin{array}{c}\text { Capital } \\
\text { Structure }\end{array}$ & Capital Share & Launching Date & $\begin{array}{c}\text { Branch Network } \\
\text { (2019) }\end{array}$ \\
\hline Bank Assafa & $350 \mathrm{MMAD}$ & I00\% Attijari Wafa Bank & July 2017 & 37 \\
\hline Umnia Bank & $600 \mathrm{MMAD}$ & $\begin{array}{c}40 \% \text { CIH Bank } \\
20 \% \text { CDG } \\
40 \% \text { QIIB }\end{array}$ & July 2017 & 32 \\
\hline Al Akhdar Bank & 225 MMAD & $\begin{array}{l}51 \% \text { GCAM } \\
49 \% \text { ICD-PS }\end{array}$ & October 2017 & 18 \\
\hline Bank Al Yousr & $340 \mathrm{MMAD}$ & $\begin{array}{c}80 \% \text { GBCP } \\
20 \% \text { Guidance Group }\end{array}$ & August 2017 & 8 \\
\hline $\begin{array}{l}\text { Bank al Tamweelwa } \mathrm{Al} \\
\text { Inma }\end{array}$ & 300 MMAD & $\begin{array}{l}\text { 5I\% BMCE Bank of Africa } \\
\text { 49\% Al Baraka Banking } \\
\text { Group }\end{array}$ & December 2017 & 5 \\
\hline
\end{tabular}

Source: Constructed by the authors based on information published on the respective websites of the three participative banks

As indicated in table I, at the end of December 2019, the number of bank branches set up by the five participative banks stood at 100, which represents 75\% of the total participative banking network.BA, the only $100 \%$ Moroccan-owned participative bank, has the largest banking network with 37 branches spread across the kingdom, followed by UB (32 branches) which is the first participative bank to start its business. While BTI, launched towards the end of 2017 with a capital of MAD 300 million owned 51\% by BMCE Bank of Africa and $49 \%$ by Al Baraka Banking Group, is present on the Moroccan banking market by five branches.

Since its validation by the CSO (Higher Council of Ulema ${ }^{1}$ ), the Murabaha contract remains the only financing contract used by the participative banking institutions. Participative banks use the three types of this contract including Murabaha Real Estate, Furniture, and Equipment.

\section{- Key Performance Indicators}

According to the statistics of the Central Bank of Morocco published in its annual report on banking supervision, real estate and automobile financing by Murabaha contract stood at nearly MAD 4 billion by the end of 2018 (Bank AL Maghrib, 2018). As indicated in figure I, financial statements published by the five participative banks by the end of 2019, reveal a total outstanding of Murabaha funds of 7 billion dirhams, representing an annual growth rate of $75 \%$. In terms of individual growth rates, BTI and $\mathrm{AAB}$ quadrupled their Murabaha assets to MAD 3 II million and MAD 90 I million, respectively.

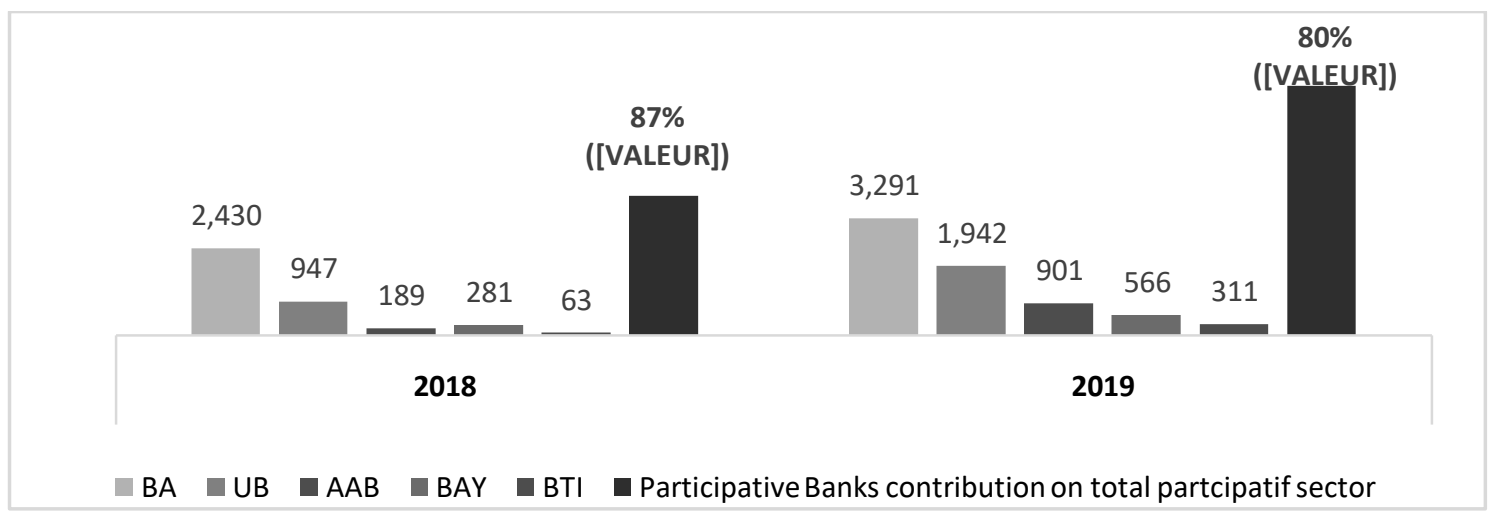

Figure I. Participative Banks Murabaha evolution (2018 - 2019 MAD million $)^{2}$

\footnotetext{
1 A body of Muslim scholars who are recognized as having specialist knowledge of Islamic sacred law and theology. https://www.lexico.com/definition/ulema
} 
About customer deposits, figure 2 confirms that the overall trend of all participative banks is upward, increasing to MAD 2.3 billion at the end of 2019 versus MAD I.4 billion a year earlier. BA continued to hold the largest share of sight deposits in the sector (38\%) with an outstanding amount of about MAD I billion, followed by UB (30\%) AAB (I2\%).

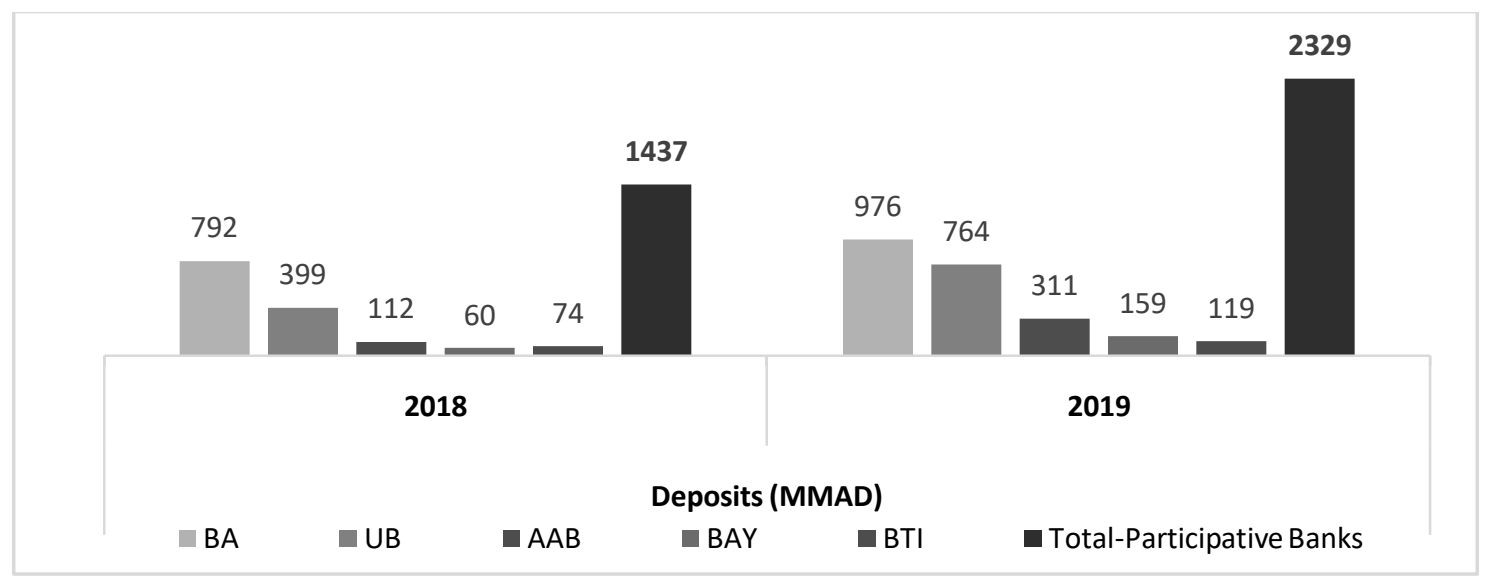

Figure 2. Participative Banks deposits evolution (2018 - 2019 MAD million) $)^{3}$

After two successive full-activity years, the overall net profit generated by the five Moroccan participative banks remains negative in 2019, marking a slight decrease of 3\% to -0.4 billion dirhams. The Figure 3 indicates that the highest deficit was recorded by UB, at I3 I million dirhams over the next two years. While the lowest deficit is 56 million dirhams recorded, doubly, by BAY and BTI.

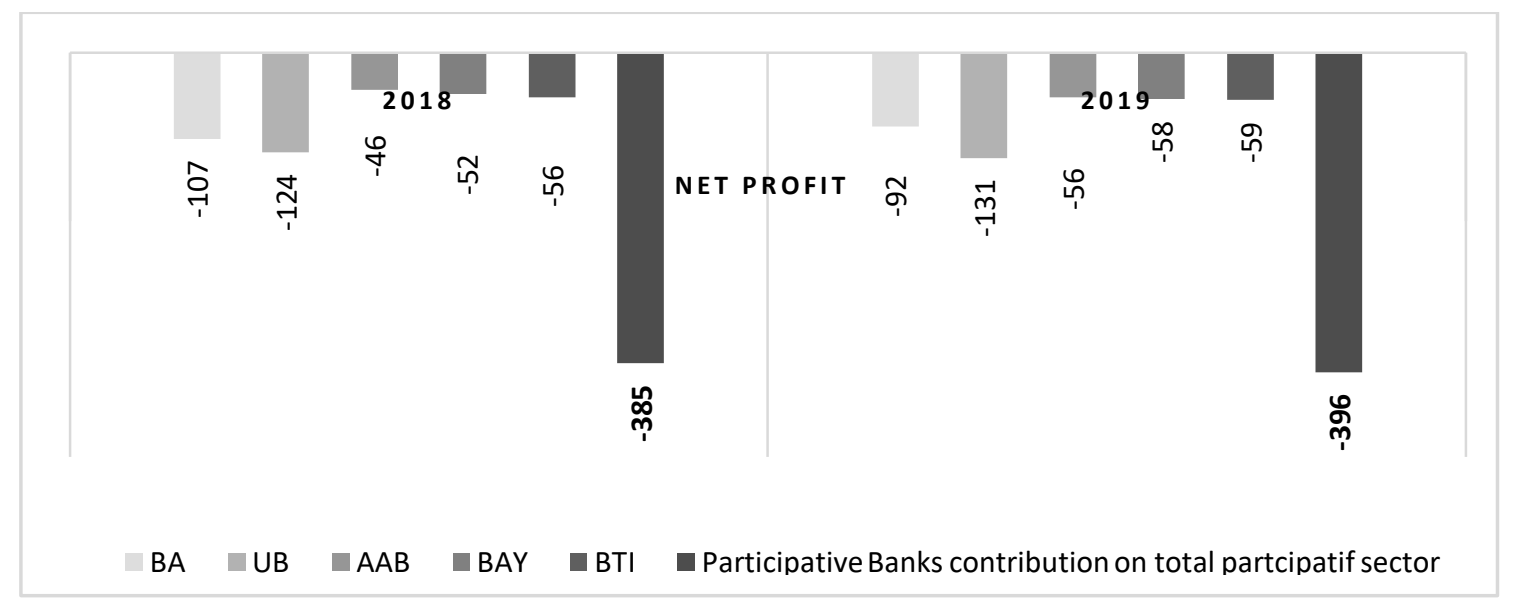

Figure 3. Participative Banks - Net Profit evolution (2018 - 20I9 MAD million) $)^{4}$

Due to all those evolutions, the Net Banking Income (NBI) of the five participative banks tripled in 2019 to I60 million dirhams, representing $80 \%$ of the NBI of the whole participative banking sector. In terms of market share, Figure 4 clearly shows that BA continues to confirm its leadership with NBI of 70 million dirhams representing $44 \%$ of participative banks' global NBI, despite a decrease of $17 \%$ compared to 2018. The market shares of UB increased 32\%, AAB recorded I2\%, and BTI's market-share changed from I\% in 2018 to 4\% one year later, with MAD 5I million, MAD I9 million, and MAD 7 million, respectively in terms of NBI. On the other hand, BAY saw its share increase to $8 \%$ with an NBI of MAD I3 million at the end of 2019.

\footnotetext{
${ }^{2}$ Constructed by the authors based on the financial statements of the five participative banks-December 2019.

${ }^{3}$ Idem.

${ }^{4}$ Idem.
} 


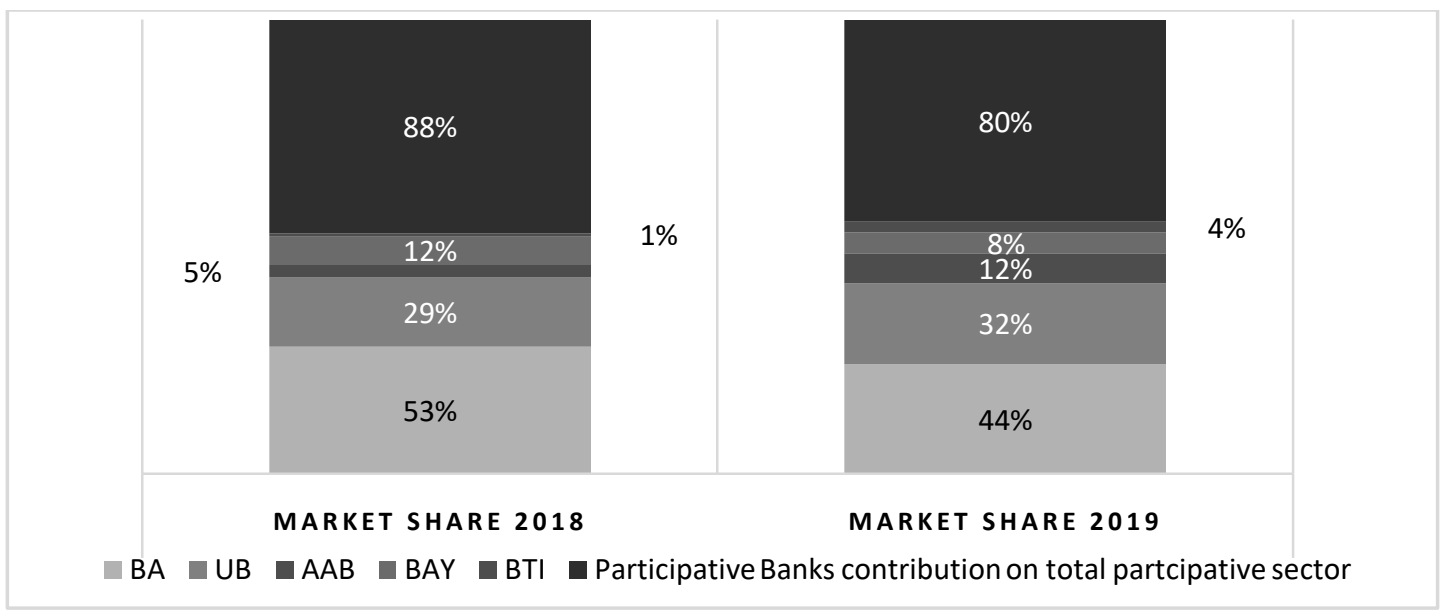

Figure 4. Participative Banks - Net banking Income Market share (2018 - 2019 MAD million $)^{5}$

\subsection{Case Study 2: The Three Moroccan Participative Windows}

A participative window is defined, according to Central bank's circular n ${ }^{\circ} 3 / \mathrm{W} / \mathrm{I} 7$ of January 27, 2017, as a dedicated structure within a conventional bank, which mobilizes resources in accordance with the opinions of the CSO to serve the needs of customers through products following the principles of sharia-compliance.

Therefore, like the participative banks and under the recommendations of the CSO, the three Moroccan participative windows have specific procedures covering all their activities, and adopt an organization that guarantees transparency and separation from their parent banks.

Table 2. Presentation of the three Moroccan participative windows

\begin{tabular}{ccccc}
\hline $\begin{array}{c}\text { Participative } \\
\text { Windows }\end{array}$ & Capital structure & Capital Share & Launching Date & $\begin{array}{c}\text { Branch Network } \\
(2019)\end{array}$ \\
\hline Dar Al Amane & 200 MMAD & $\begin{array}{c}\text { I00\% Société Générale } \\
\text { Maroc }\end{array}$ & September 20I7 & I3 \\
\hline Arreda & 200 MMAD & I00\% Crédit du Maroc & January 2018 & 6 \\
\hline Najmah & 200 MMAD & $\begin{array}{c}\text { I00\% BMCI - BNP } \\
\text { PARIBAS }\end{array}$ & February 2018 & I4 \\
\hline
\end{tabular}

Source: Constructed by the authors based on information published on the respective websites of the three participative banks

As indicated in Table 2 above, the first participative window of the Moroccan banking sector was created in September 2017. It is Dar Al Amane (DAA) which is a subsidiary of Société Générale Group and which was created with a capital of 200 million dirhams. Since then, DAA has developed its commercial network to reach 13 branches $100 \%$ dedicated to participative banking activity.

Then, Arreda (ARR), the participative window of Credit of Morocco, launched its activity in early 2018 and invested in 6 branches 100\% dedicated to the participative banking activity. In the other hand, the BMCI label includes I4 dedicated spaces within his conventional branches for the activity of its participative window Najmah (NAJ), since 2018.

\section{- Key Performance Indicators}

Like participative banks, participative windows offer banking products and services, in line with CSO recommendations, for individuals, professionals, and corporate. The Murabaha product is the only financing solution commercialized under three types of contract validated by the CSO (Real Estate, Automobile, and Equipment Murabaha contracts).

The overall Murabaha stock of the three windows almost doubled in 2019 and reached I.7 billion dirhams, of which MAD I.3 billion (77\%) is owned by DAA. Also, ARR and NAJ contributed to this evolution with $16 \%$ and $6 \%$ respectively. These evolutions are illustrated in graph figure 5 . 


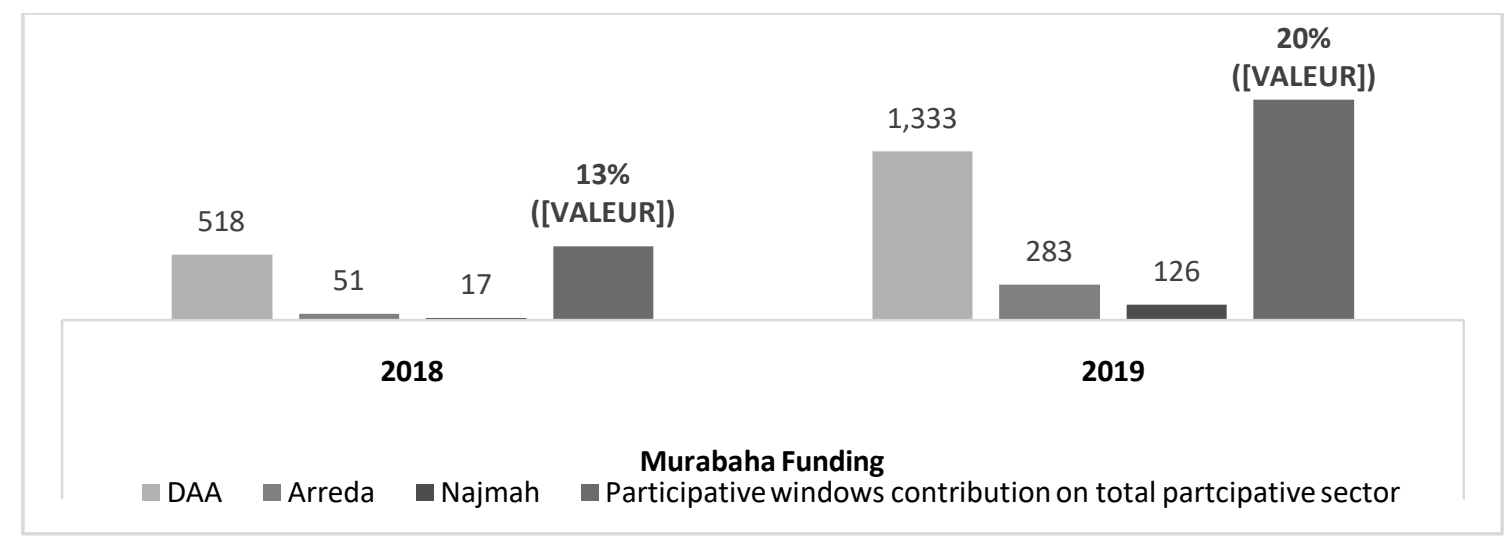

Figure 5. Participative Windows - Murabaha funding evolution (2018 - 2019 in million MAD) ${ }^{6}$

On the other hand, as illustrated in Figure 6, the stock of customer deposits followed the upward trend of the Murabaha financing stock and reached 226 million dirhams at the end of 20I9, representing 91\% of the overall stock of the whole participative banking sector. It should be noted that DAA is the leader with a market share of $89 \%$, followed by ARR $(9 \%)$ and $\mathrm{NAJ}(2 \%)$.

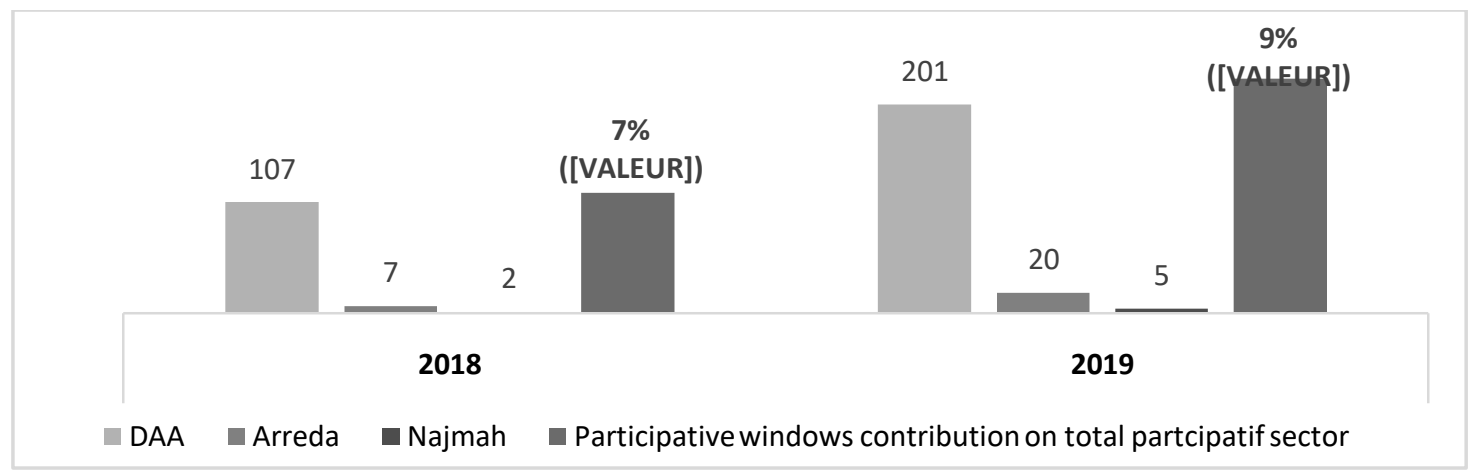

Figure 6. Participative Windows - Customers deposits evolution (2018 - 2019 MAD million) ${ }^{7}$

At the end of 2019, although being negative, the overall Net Profit (NP) recorded by the three participative windows improved by $24 \%$ to more than MAD 23 million, as indicated in figure 7 below. This improvement was driven by $60 \%$ by the positive increase in DAA's NP (MAD - I4 million) and 39\% by the only positive result of the whole sector recorded by NAJ (MAD 0.4 million).

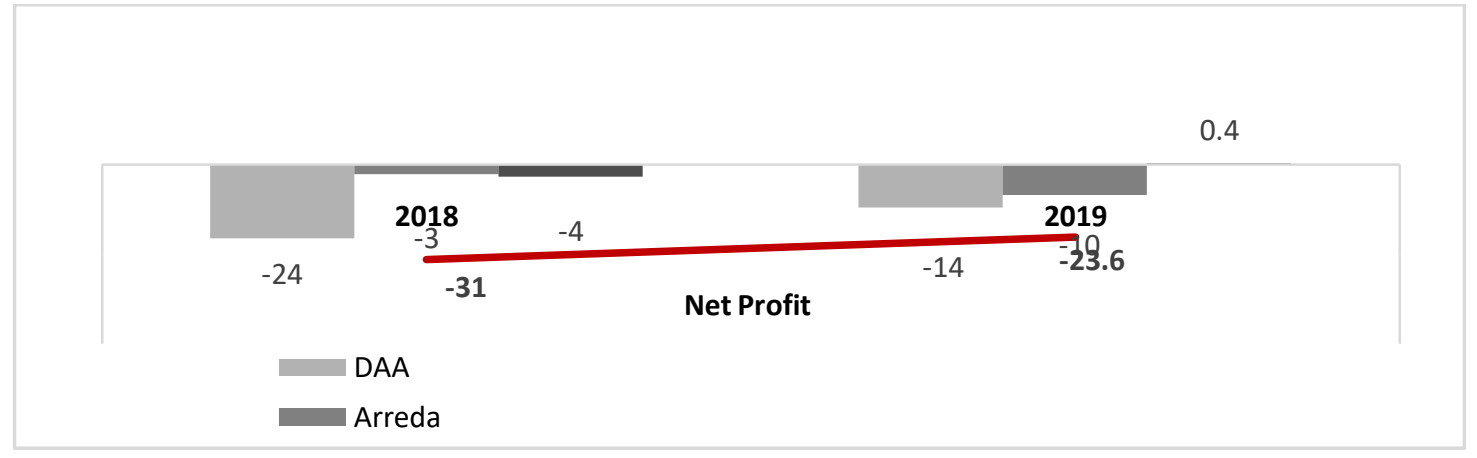

Figure 7. Participative Windows -Net Profit evolution (2018 - 20I9 MAD million $)^{8}$

${ }^{6}$ Constructed by the authors based on the financial statements of the three participative windows- December 2019.

${ }^{7}$ Idem. 
For its part, Net Banking Income (NBI) of the three windows also increased sharply from MAD 8 million in 2018 to MAD 40 million in 2019. Figure 8 illustration shows that over 2018 and 2019, DAA is the leader and holds the largest share of the total NBI (90\% - 78\%), followed by NAJ ( $8 \%-13 \%)$ and ARR (3\% - I0\%).

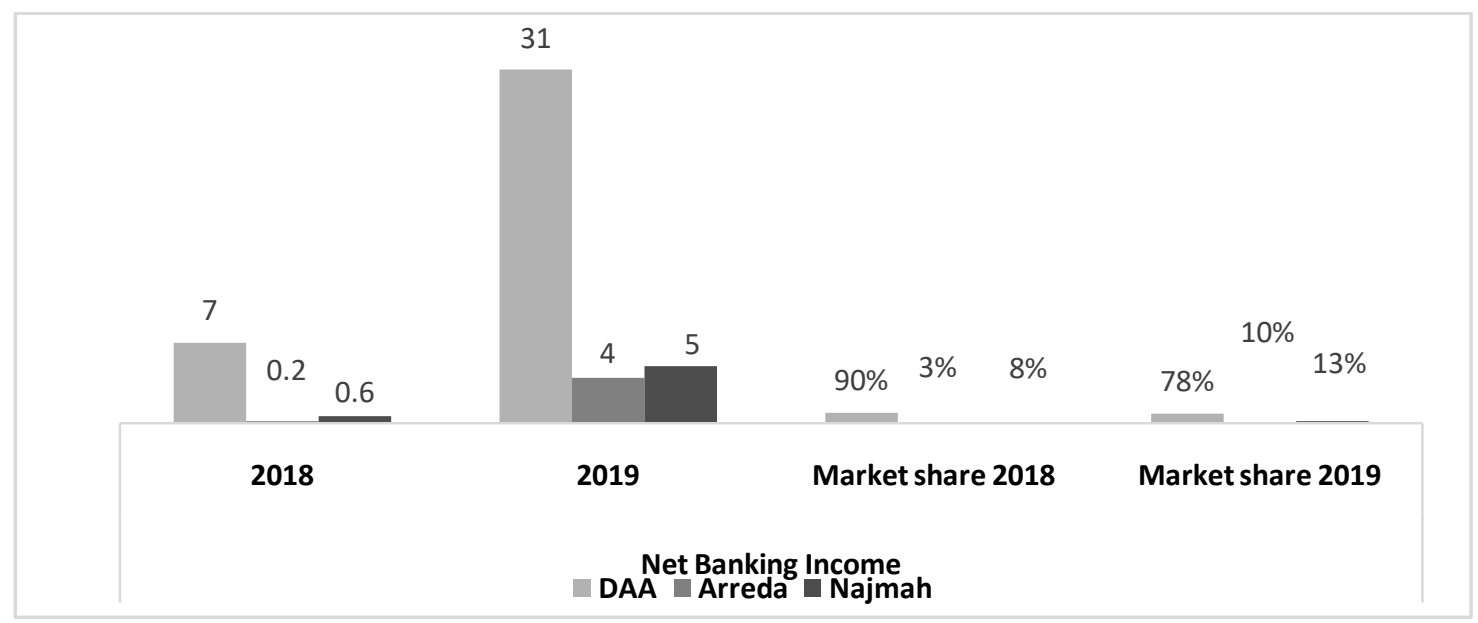

Figure 8. Participative Windows-Net banking Income evolution (2018 - 2019 MAD million $)^{9}$

\subsection{SWOT Analysis: Moroccan Participative Banking Institutions through Their Financial Ecosystem}

The participative financial ecosystem in Morocco has particularities due to the multiplicity of its players, namely, Bank Al Maghrib (BAM), the Ministry of Economy and Finance, the Insurance Control Authority and Social Welfare (ACAPS), the Moroccan Capital Market Authority (AMMC) and the National Committee of Participative Finance in the Higher Council of Ulema (CSO).

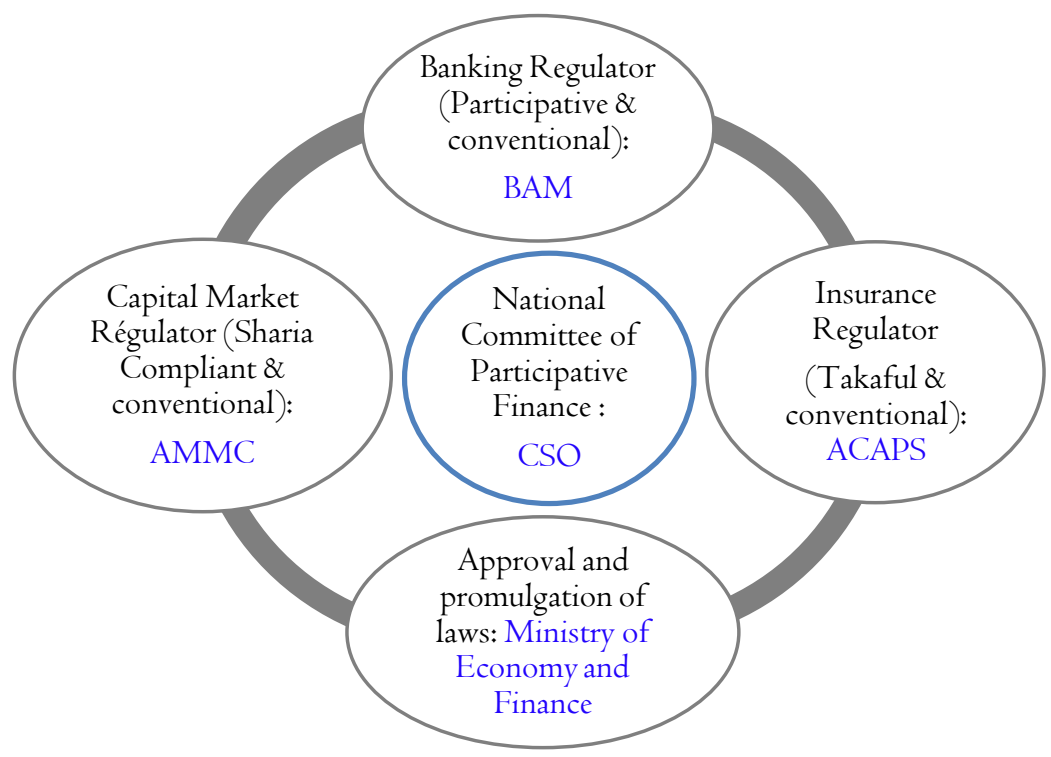

Figure 9. Moroccan Participative Financial Ecosystem ${ }^{10}$

\footnotetext{
${ }^{8}$ Idem.

${ }^{9}$ Idem.

${ }^{10}$ Constructed by the authors.
} 
The creation of a centralized Sharia committee in the High Council of Ulemas (CSO) (Figure 9) demonstrates a concern for legislative and regulatory coherence. This committee is the only one authorized to decide on the compliance with Sharia law of all the products and services of the operators of the banking and financial market.

On the basis that both are first and foremost banks, the central bank of Morocco introduced a single banking law in December 2014 for both conventional and participative banks. Therefore, this implies, for all, respect for the entire regulatory arsenal that regulates banking activity in terms of prudential rules, governance, reporting, etc. However, this ecosystem remains incomplete and suffers from several shortcomings and many gaps such as the absence of TAKAFUL insurance, participative interbank market, Sharia Compliant capital market, etc. Table 3 presents a conclusion of our analysis of the main strengths, weaknesses, opportunities, and threats of Moroccan participative banking sector.

Table 3. SWOT-Analysis of Moroccan Participative Banking Sector

\begin{tabular}{|c|c|}
\hline Strengths & Weaknesses \\
\hline $\begin{array}{l}\text { Evolving, even if it's modest, business and financial } \\
\text { performance; } \\
\text { Increasingly large banking network, covering many } \\
\text { parts of the kingdom; } \\
\text { Ram up of Murabaha funding; } \\
\text { Young developing banking industry, based on the } \\
\text { compliance of all its transactions with Sharia } \\
\text { principles. }\end{array}$ & $\begin{array}{l}\text { Increased risk mapping compared to conventional banks; } \\
\text { 'ery large investment and operating expenses absorbing } \\
\text { resources and creating a great need for liquidity; } \\
\text { Murabaha is the only financing product commercialized; } \\
\text { imited banking products, particularly in relation to services } \\
\text { associated with the bank account; } \\
\text { Lack of publicity and communication; } \\
\text { Huge lack of doubly qualified and experienced human resources } \\
\text { in the field. }\end{array}$ \\
\hline
\end{tabular}

\begin{tabular}{|c|c|}
\hline Opportunities & Threats \\
\hline $\begin{array}{l}\text { Sharia-board centralized at the committee created } \\
\text { within the CSO and standardized Sharia compliance } \\
\text { rules; } \\
\text { New financing contracts (Salam, Mudaraba) being } \\
\text { validated by the CSO; } \\
\text { The existence of a Moroccan population, out of } \\
\text { religious conviction, accepting only Sharia-compliant } \\
\text { banking transactions; } \\
\text { Creation of Casa Finance Hub to prepare Morocco } \\
\text { to be Africa's financial hub. }\end{array}$ & $\begin{array}{l}\text { The incompleteness of the participative financial ecosystem, } \\
\text { particularly in terms of the participative interbank's market } \\
\text { and Takaful insurance; } \\
\text { Slow processes for validating products and financing contracts } \\
\text { by the CSO; } \\
\text { Strong conventional banking sector; } \\
\text { Lack of public awareness of the principles and the products of } \\
\text { participative banking institutions. }\end{array}$ \\
\hline
\end{tabular}

Source: Constructed by the authors.

\subsection{Benchmark Study: Turkey Participation Banking Sector}

The existence of Islamic finance in Turkey is ancient, dating back to the time of the Ottoman Empire. After the fall of the latter, Islamic financial activity virtually disappeared from the country before being reintroduced modestly, again, into the Turkish financial sphere in 1985 (Karakuzu \& Yilmaz, 2014) as part of the liberalization program pursued by Turgut Özal's premiership (1983-89). However, due to the laicist political culture of the time, Islamic banks were called "Special Finance Houses", without any express reference to their Islamic nature (Asutay, 2013). It was only after two decades that it began to grow, gradually in the country, thanks to its approval by government authorities and the amendment of the banking law in 2005. Thus, this law officially introduced Islamic banking activity in the banking sphere and changed the appointment of its players to" Participation Banks"(Cekici, 2019).

In 2017, the Turkish banking landscape included five participation banks, two of which are state-owned banks called Ziraat Katilim Bankasi and Vakif Katilim Bankasi. The other three banks, namely Albaraka Turk and Kuveyt Turk, are considered by the legislature to be private banks (Cekici, 2019). In 2018, the banking supervisory authority BDDK introduced a new operator Emlak Katilim Bankasi, thus increasing the number of participation banks in the country to six. Table 4 presents the main key indicators of the commercial and financial performances of Turkey participation banks by the end of 2018 . 
Table 4. Key indicators of Turkey Participation Banking Sector (2018 - TL million)

\begin{tabular}{lccc}
\hline Indicators & Dec-I8 & Dec-I7 & Change (\%) \\
\hline Funds collected & $\mathrm{I} 37220$ & $\mathrm{I053I0}$ & 30,3 \\
\hline Funds allocated & $\mathrm{I} 24562$ & $\mathrm{I06733}$ & $\mathrm{I} 6,7$ \\
\hline Total asset & 206806 & $\mathrm{I} 60 \mathrm{I36}$ & $29, \mathrm{I}$ \\
\hline Net profit & $2 \mathrm{I} 23$ & $\mathrm{I} 583$ & $34, \mathrm{I}$ \\
\hline Number of staff & $\mathrm{I} 5654$ & $\mathrm{I} 5029$ & 4,2 \\
\hline Number of Branches & $\mathrm{II} 22$ & $\mathrm{I} 032$ & 8,7 \\
\hline
\end{tabular}

Source : TKBB Report - 2018

At the end of 20I8, the participation banks had a total of I,I22 branches, constituting approximately $8 \%$ of the banking sector's total branch. Also, the demand for Islamic banking and financial services in the country is growing at a rapid pace. According to statistics published by Turkey's Participation Banks Association (TKBB) (2018), the assets of the five operational Turkish banks reached TL 207 billion compared to TL 160 billion in the previous year, registering a growth rate of $98 \%$ in just 4 years (Figure 9).

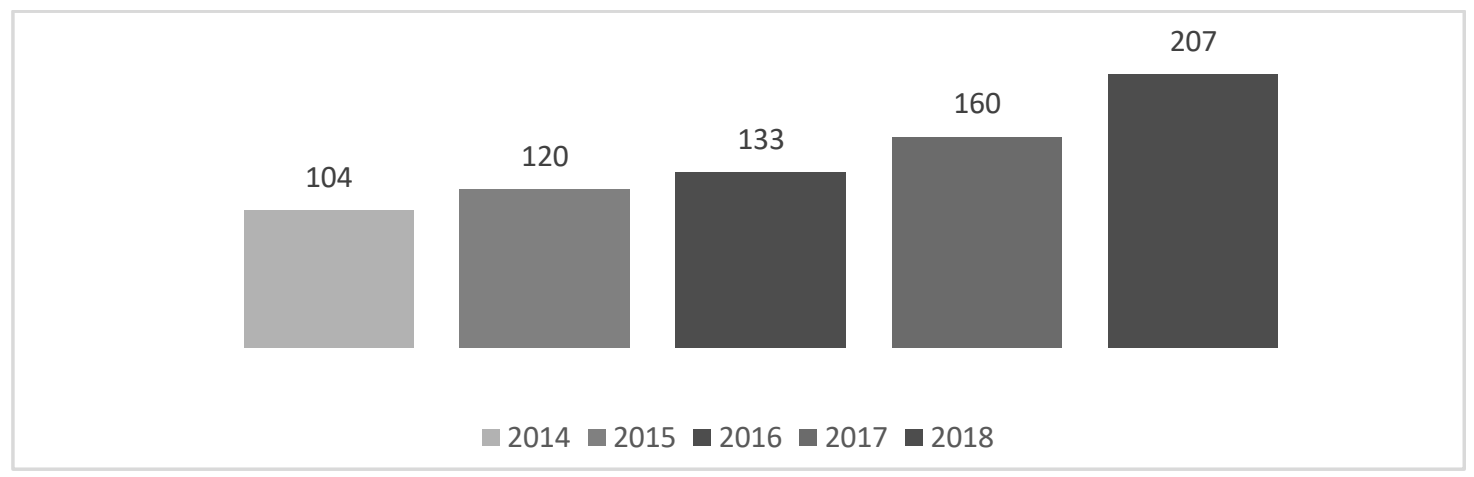

Figure 9.Turkish Participation Banks - Total assets evolution (20I4 - 2018 TL billion) ${ }^{11}$

According to the same source, the total outstanding funding allocated to customers by the five Turkish participation banks reached TL I 24 billion at the end of 2018 compared to TL I07 billion a year earlier. Similarly, the total stock of deposits collected increased significantly by $30 \%$ to TL 137 billion in 2018.

Because of the increase in outstanding financing and deposits, all banks in the participation sector recorded a good financial performance in 20I8, with an overall Net Profit (NP) of TL 2 billion (Figure I0), an increase of 34\% over one-year Kuveyt Turk is the largest participation bank in terms of its asset volume with TL 870 million in 20I8. The second-highest NP (TL 445 million) is recorded by Turkiye Finans, followed by Vakif Katilim Bankasi (325 million TL). While Ziraat Participation and Albaraka Turk recorded an asset of TL 323 million and TL I34 million, respectively.

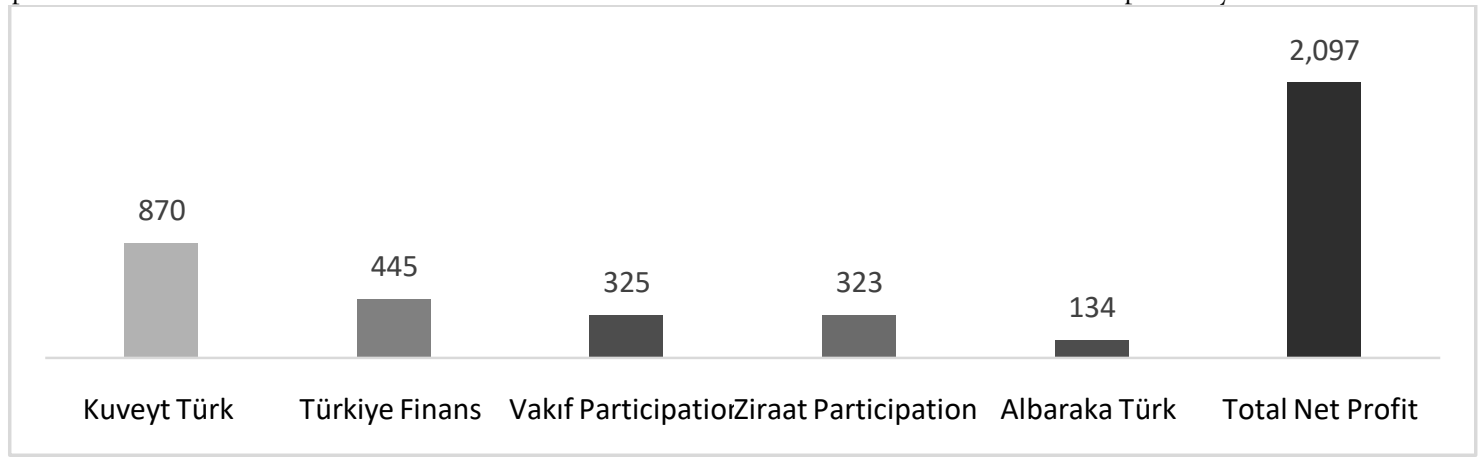

Figure I0. Turkish Participation Banks - Net profit evolution (2018 - TL million) ${ }^{12}$

${ }^{11}$ Participation Banks Association of Turkey - https://www.tkbb.org.tr/en 
Moreover, in a recent report, Moody's (2020) estimated that the Turkish government's initiatives will further stimulate the growth of the assets of participatory banks, which are expected to double over I0 years. Among these incentives, the Turkish state has guaranteed loans for non-financial companies and has introduced a tax regime allowing tax reductions for participation banking activities, as well as relaxed banking provisions, to encourage the creation of new participation banks.

Participation banking had a difficult start in Turkey, coping with ideological prejudice and disadvantages of restrictive legislation. Although most of the obstacles were tackled one by one, there are still some challenges that are holding back the expansion of Turkish participation banks. According to Ceylan \& Karadeniz (2019), the participation banks do not have the same resources that conventional banks possess, lacking the required capital such as funds or trained staff for opening a new branch and suffering from a huge lack of awareness of how the industry works, among a large part of Turkish Population (Table $5)$.

Table 5. SWOT-Analysis of Turkey Participation Banking Sector

\begin{tabular}{l}
\hline Strengths \\
\hline - An asset growth rate of 99\% from 2014 to 20I8; \\
- Positive net profits that exceed TL 2 billion. \\
- $\quad$ Progressive and promising commercial performances; \\
- $\quad$ Large banking network (more than I million branches); \\
- Increasing demand for Islamic Banking products and \\
$\quad$ services.
\end{tabular}

\begin{tabular}{l} 
Weaknesses \\
\hline - Cartographie de risques accentuée par rapport aux \\
banques conventionnelles notamment le risque \\
commercial déplacé ; \\
- Dependenceon Murabaha funding; \\
- Divergences in sharia compliant banking practices; \\
- Dire need oftrained and skilled workforces.
\end{tabular}

\section{Opportunities}

- Existence of Takaful insurances;

- Tax flexibility and flexible banking arrangements;

- Establishment of Global Islamic Finance Center in Istanbul by Word Bank;

- Establishment of the Istanbul international financial center which would help to attract foreign investors;

- Increase of public and private Sukuk insurances;

- Introducing Islamic Finance programs in graduation, post-grad, and Ph.D. degree level.

\section{Source: Constructed by the authors}

Like the choice of the Moroccan legislator, Turkey has opted for a single banking law governing both the participative banking and the conventional banking sectors. Nevertheless, according to the findings of the benchmark study, the financial ecosystem in Turkey is much more developed, open, and has several years of experience in participation finance, compared to Morocco. As a result, this has encouraged the growth of Turkish participation banks, whose asset growth rate reached $99 \%$ between 2014 and 20I8. The five operating banks recorded positive net profits more than TL 2 billion by the end of 2018 and their business performance is very promising. Having almost 40 years of history, the current market share of Turkish participation banking sector currently has reached 5\% to 6\% (Ceylan \& Karadeniz, 2019), that remains too small, compared with Malaysia (33\%) and Middle Eastern countries (I5\% - 77\%).

\section{Conclusion}

This paper explored the current state of the recent participative banking sector in Morocco with its five banks and three windows. With a global Islamic banking market estimated at USD 2,5 billion by the end of 2019, this segment of Islamic finance remains embryonic in Morocco. After closing the first two full-year of activity, the five banks and three participative windows recorded a total balance sheet of MAD 7.3 billion compared to MAD 2.6 billion a year earlier. While this reflects a rise in Murabaha funding, the importance of the business launch loads weighs heavily on results that remain negative.

On the other hand, the paper presents a general benchmark of the participation banking sector in Turkey. The aim was to highlight the main divergence and convergence points between the two participative banking systems. Both Morocco and Turkey have opted for a single banking law incorporating participation banking activity alongside conventional banking.

${ }^{12}$ Constructed by the authors based on TKBB's report - 2018 . 
However, according to the findings of the benchmark study, the financial ecosystem in Turkey is much more developed, open, and has several years of experience in participation finance, compared to Morocco. As a result, this has encouraged the growth of Turkish participation banks, whose asset growth rate reached $99 \%$ between 2014 and 2018 .

Table 6. Main similarities and differences between the participative banking sector of Morocco and Turkey

\begin{tabular}{|c|c|c|c|}
\hline $\begin{array}{l}\text { Indicators (2018- } \\
\text { 20I9) }\end{array}$ & $\begin{array}{l}\text { Morocco participative } \\
\text { banking sector }\end{array}$ & $\begin{array}{l}\text { Turkey participation } \\
\text { banking sector }\end{array}$ & Conclusions \\
\hline $\begin{array}{l}\text { Launching year of the } \\
\text { participative banking } \\
\text { activity }\end{array}$ & 2017 & 1985 & $\begin{array}{l}\text { The existence of Islamic finance in Turkey is } \\
\text { ancient, dating back to the time of the } \\
\text { Ottoman Empire. Morocco is the last Muslim } \\
\text { country to introduce Islamic finance into its } \\
\text { national financial sphere. }\end{array}$ \\
\hline $\begin{array}{l}\text { Banking law/ } \\
\text { Banking supervisory } \\
\text { authority }\end{array}$ & $\begin{array}{c}\text { Banking law } \mathrm{n}^{\circ} \mathrm{IO}-\mathrm{I} 2 \\
\text { of 20I5/ } \\
\text { BAM }\end{array}$ & $\begin{array}{c}\text { Banking law } \mathrm{n}^{\circ} 54 \mathrm{II} \\
\text { of } 2005 / \mathrm{BDDK}\end{array}$ & $\begin{array}{l}\text { Both countries have a single banking law } \\
\text { incorporating participation banking activity } \\
\text { alongside conventional banking. }\end{array}$ \\
\hline $\begin{array}{l}\text { The participative } \\
\text { financial ecosystem }\end{array}$ & $\begin{array}{l}\text { Embryonic and } \\
\text { incomplete }\end{array}$ & $\begin{array}{l}\text { Developed and } \\
\text { completed }\end{array}$ & $\begin{array}{l}\text { The participative financial ecosystem in } \\
\text { Morocco mainly suffers from the absence of } \\
\text { Takaful and participative interbank market. }\end{array}$ \\
\hline $\begin{array}{l}\text { Number of } \\
\text { participative banks }\end{array}$ & $\begin{array}{l}\text { Five banks and three } \\
\text { windows }\end{array}$ & $\begin{array}{c}\text { Six banks but only } \\
\text { five were operational } \\
\text { in } 2018 \\
\end{array}$ & $\begin{array}{l}\text { There is no participative banking window in } \\
\text { Turkey. }\end{array}$ \\
\hline $\begin{array}{l}\text { Total number of } \\
\text { branches }\end{array}$ & 133 & I I22 & $\begin{array}{l}\text { Turkey has } 989 \text { more participative banking } \\
\text { branches than Morocco. }\end{array}$ \\
\hline Total assets & MAD I3 billion & TL 207 billion & $\begin{array}{l}\text { Morocco's participative banking sector is } 16 \\
\text { times smaller than the Turkish one. }\end{array}$ \\
\hline Net Profit & -MAD 0,4 billion & TL 2 billion & $\begin{array}{l}\text { While the global net profit of Moroccan } \\
\text { participative banking is negative, the Turkish } \\
\text { one has increased by } 34.1 \% \text { from TL I,583 } \\
\text { million in } 2017 \text { to TL } 2,124 \text { million in } 2018 \text {. }\end{array}$ \\
\hline
\end{tabular}

Source: Constructed by the authors

The study concludes that the development of the participative banking activity in Morocco is hampered by an embryonic and incomplete ecosystem suffering mainly from the absence of Takaful insurance and the lack of a participative interbank market. Being young and new, this industry still leaves nuances and areas of uncertainty with the public because of the lack of awareness of the principles, operations, and products offered by the players of the participative banking sector. Thus, there is still a long way to go for the participative banking industry, before it can flourish and move forward in a highly competitive environment.

\section{References}

Amrani, O., \& Najab, A. (2020). L'évolution de la gouvernance bancaire: d'une approche classique vers une approche fondée sur la charia (revue de littérature). Revue du Contrôle de La Comptabilité et de l'Audit, 4(3), 822-847.https://doi.org/I0.528I/zenodo.3605633

Asutay, M. (2013). The development of Islamic banking in Turkey: Regulation, performance and political economy. Islamic Finance in Europe.

Retrieved from https://www.elgaronline.com/view/edcoll/978I781002506/9781781002506.00026.xml

Bank Al Maghrib. (2018). Rapport annuel sur la supervision bancaire 2018. 78. Retrieved from http://www.bkam.ma/Supervision-bancaire/Indicateurs-et-publications/Rapport-annuel-sur-la-supervisionbancaire/Rapport-annuel-sur-la-supervision-bancaire-exercice-2018

Bari, I., \& Radi, B. (20I I). Au-delà de la crise. La finance islamique est-elle un moyen de régulation ?. Éthique publique. Revue internationale d'éthique sociétale et gouvernementale, vol. I3, nº 2 .

Cekici, I. Z. (2019). Participative Banking in Turkey - Islamic Finance in Europe: A Cross Analysis of IO European Countries. Springer International Publishing, 29 I-3I6. 
Ceylan, A \& Karadeniz, M. A. (2019). Islamic Finance challenges in Turkey. Special Report. Retrieved from https://gratanet.com/publications/islamic-finance-challenges-in-turkey

Hasan, M. \& Dridi, J. (2012). The effects of the global crisis on Islamic and conventional banks: a comparative study . Journal of International Commerce, Economics and Policy n $n^{\circ} 02,47$.

Hassoune, A. (2003). La solvabilité des banques islamiques: Forces et faiblesses. Revue d'économie financière, 72(3), 277-297.

IFDI. (2019). Islamic Finance Development Report 2019.24. Retrieved from https://icdps.org/uploads/files/IFDI\%202019\%20DEF\%20digitalI 574605094_72I4.pdf

IFAAS. (2014). Morocco Islamic Finance - Unlocking the Kingdom's Potential. Thomas Reuters. Retrieved from https://documents.pub/document/morocco-islamic-finance-20I4-unlocking-the-kingdoms-potential-thomasreuters.html

Karakuzu, B., \& Yilmaz, Ş. (20I4). Turkey aims to become center of Islamic finance.In-Depth/Islamic Finance,48-53.

Participation Banks Association of Turkey. (2018). Participation Banks report 2018. Retrieved from https://www.tkbb.org.tr/Documents/Yonetmelikler/Participation-Banks-2018-Sector-Report.pdf

Rashwan, M. H., \& Ehab, H. (2016). Comparative Efficiency Study between Islamic and Traditional Banks. Journal of Finance and Economics, 4(3), 74-87.

Moody's. (2020). Turkish Islamic banking set for fast growth after a slow start-Moody's. (s. d.). Retrieved fromhttps://www.moodys.com/research/Moodys-Turkish-Islamic-banking-set-for-fast-growth-after-slow-PBC_I2I0882

Turkey's Participation Banks Association (TKBB's) Report. (2018). Retrieved from https://www.tkbb.org.tr/en

\section{Copyrights}

Copyright for this article is retained by the author(s), with first publication rights granted to the journal. This is an open-access article distributed under the terms and conditions of the Creative Commons Attribution license (http://creativecommons.org/licenses/by/4.0/). 